\title{
Determination of macromineral requirements for preweaned dairy calves in tropical conditions
}

\author{
M. M. D. Castro, ${ }^{1}$ A. L. Silva, ${ }^{1 *}$ L. F. Costa e Silva, ${ }^{1}$ P. P. Rotta, ${ }^{1}$ T. E. Engle,${ }^{2}$ and M. I. Marcondes ${ }^{1} \dagger$ \\ ${ }^{1}$ Department of Animal Science, Universidade Federal de Viçosa, 36570-000 Viçosa, Minas Gerais, Brazil \\ ${ }^{2}$ Department of Animal Science, College of Agricultural Sciences, Colorado State University, Fort Collins 80523
}

\begin{abstract}
International committees that have published nutrient requirements for dairy cattle have used data from mineral studies conducted in the 1920 s to 1970 s, and no study has reported data from animals less than 100 $\mathrm{kg}$; therefore, there is a need to update mineral requirements for preweaned dairy calves. Thus, a meta-analysis was performed to estimate the mineral requirements of $\mathrm{Ca}, \mathrm{P}, \mathrm{K}, \mathrm{Mg}$, and $\mathrm{Na}$ for Holstein and Holstein $\times$ Gyr crossbred preweaned dairy calves using data from 5 studies developed at the Universidade Federal de Viçosa (Viçosa, MG, Brazil). A total of 210 calves were separated into 2 breeds: purebred Holstein calves (animals with a Holstein pedigree higher than 87.5\%) and Holstein $\times$ Gyr crossbred calves (animals with a Holstein pedigree lower than $87.5 \%$ ). The comparative slaughter technique was used to estimate animal body composition and empty body weight (EBW). Mineral requirements for maintenance were estimated by the regression between retained mineral and mineral intake, whereas mineral requirements for gain were obtained from the first derivative of the mineral content in the animal's body. In addition, breed effect was tested on the intercept and slope of the models. The effect of breed was not observed for all analyzed variables. Thus, net requirements for maintenance were 12.73, 11.81, $20.28,3.50$, and $6.37 \mathrm{mg} / \mathrm{kg}$ of EBW per day for $\mathrm{Ca}$, $\mathrm{P}, \mathrm{K}, \mathrm{Mg}$, and $\mathrm{Na}$, respectively. Retention coefficients were $73.18,65.20,13.16,29.55$, and $24.28 \%$ for $\mathrm{Ca}$, $\mathrm{P}, \mathrm{K}, \mathrm{Mg}$, and $\mathrm{Na}$, respectively. The following equations were determined to estimate net requirements for gain $(\mathrm{NRG}, \mathrm{g} / \mathrm{d})$ : NRG for $\mathrm{Ca}=14.402 \times \mathrm{EBW}^{-0.139}$ $\times$ empty body gain $(\mathrm{EBG})$; $\mathrm{NRG}$ for $\mathrm{P}=5.849 \times$ $\mathrm{EBW}^{-0.027} \times \mathrm{EBG}$; NRG for $\mathrm{K}=1.140 \times \mathrm{EBW}^{-0.048} \times$ $\mathrm{EBG}$; $\mathrm{NRG}$ for $\mathrm{Mg}=0.603 \times \mathrm{EBW}^{-0.036} \times \mathrm{EBG}$; and

Received June 5, 2018.

Accepted October 16, 2018.

*Current address: Institute of Animal Science, Department of Animal Production, Universidade Federal Rural Do Rio de Janeiro, $\mathrm{km} \mathrm{47,} \mathrm{Seropédica,} \mathrm{Rio} \mathrm{de} \mathrm{Janeiro} \mathrm{23897-005,} \mathrm{Brazil.}$

†Corresponding author: marcos.marcondes@ufv.br
\end{abstract}

$\mathrm{NRG}$ for $\mathrm{Na}=1.508 \times \mathrm{EBW}^{-0.045} \times \mathrm{EBG}$. Due to the high variation between the data found in this study and in the available literature, we suggest that further studies should be conducted to evaluate the estimates of this study.

Key words: growth, maintenance, mineral, retention coefficient

\section{INTRODUCTION}

Minerals play essential functions in the body (i.e., structural, physiological, catalytic, regulatory, and immune response; Suttle, 2010; Wilson et al., 2016), although they are found in small concentrations compared with other nutrients such as fat and protein. Therefore, a deficiency in minerals can compromise the productivity and reproductive performance of livestock (Miranda et al., 2006). Minerals are extremely important in animal nutrition; however, the information available in the literature regarding mineral requirements for preweaned dairy calves raised under tropical conditions is scarce (Signoretti et al., 1999; Fonseca et al., 2012). Additionally, to the best of our knowledge, there is a void of studies estimating mineral requirements for Holstein (Bos taurus) and Holstein $\times$ Gyr (Bos indicus) crossbred preweaned dairy calves raised in tropical conditions. Consequently, diet formulation is based on mineral requirements reported by international councils (ARC, 1980; AFRC, 1991; NRC, 2001; CSIRO, 2007), where NRC (2001) is the most commonly used publication for formulating diets for growing dairy calves. The NRC (2001) suggests fixed recommendations of mineral concentrations in the diet of preweaned dairy calves regardless of BW, genetic makeup, or animal performance.

In addition, animals used by NRC (2001) to estimate minerals requirements are different from those raised under tropical conditions in terms of genetic composition, management, feeding strategies, and climatic conditions (Embrapa, 2009). The only nutrient requirements developed for cattle living under tropical conditions are those of BR-CORTE (2016). However, BR- 
CORTE (2016) estimates the nutrients for beef breeds only. Moreover, BR-CORTE (2016) estimates the net mineral requirements for growing Zebu calves up to $180 \mathrm{~d}$ of age. The BR-CORTE (2016) requirements did not estimate mineral requirements of maintenance and retention coefficients (RC) for calves below $90 \mathrm{~kg}$ and used estimates obtained from adult beef cattle. Thus, estimates of nutrient requirements of minerals for dairy calves during the preweaning phase $(\sim 110 \mathrm{~kg}$ of $\mathrm{BW})$ remain scarce.

The macromineral requirements for gain for dairy calves estimated by NRC (2001) are based on a few studies (e.g., Moulton et al., 1922; Ellenberger et al., 1950; Hansard et al., 1957; Schulz et al., 1975; Gueguen et al., 1989) published in the 1950s, 1970s, and 1980s. However, dairy cattle have undergone intense genetic selection over the last decade (Oltenacu and Broom, 2010). This selection has drastically improved animal performance and possibly altered nutrient requirements. Moreover, feeding management of dairy calves has changed drastically from a traditional management of $10 \%$ of BW in liters of milk (Khan et al., 2007) to volumes greater than $8 \mathrm{~L} / \mathrm{d}$ or ad libitum milk supply. By increasing liquid consumption, calf performance has also increased (Silva et al., 2015). The improvement in genetic composition has been coupled with better sanitary and nutritional management, which might have contributed to changes in mineral requirements for milk-fed calves.

We hypothesized that macromineral requirements of Holstein calves are different from those of Holstein $\times$ Gyr crossbred calves raised under the same conditions. In addition, we hypothesized that the estimates of dietary mineral requirements from NRC (2001) and BR-CORTE (2016) are not suitable for dairy calves. Therefore, a meta-analysis was developed to estimate the macromineral requirements of $\mathrm{Ca}, \mathrm{P}, \mathrm{K}, \mathrm{Mg}$, and $\mathrm{Na}$ for maintenance and gain of Holstein and crossbred Holstein $\times$ Gyr dairy calves raised under tropical conditions.

\section{MATERIALS AND METHODS}

This study was not submitted to the Ethics Committee of Animal Care and Use because we used only data from studies that were previously conducted. However, all individual studies followed the appropriate guidelines for animal care and use.

\section{Data Acquisition}

The database used to estimate macromineral requirements $(\mathrm{Ca}, \mathrm{P}, \mathrm{K}, \mathrm{Mg}$, and $\mathrm{Na}$ ) comprised 5 studies conducted at Federal University of Viçosa (Jolomba, 2015;
Silva et al., 2015; Rodrigues et al., 2016; Dias et al., 2017; Chagas et al., 2018) totaling 210 calves. In each study, individual information of each mineral $(\mathrm{Ca}, \mathrm{P}, \mathrm{K}$, $\mathrm{Mg}$, and $\mathrm{Na}$ ) was collected for mineral intake (MI; g/d), retained mineral (RM; g/d), and mineral body content (h; Tables 1 and 2). In addition, breed data (Holstein or Holstein $\times$ Gyr $)$, initial empty BW $(\mathbf{E B W} ; \mathrm{kg})$, final $\mathrm{EBW}(\mathrm{kg})$, empty body gain $(\mathbf{E B G} ; \mathrm{kg} / \mathrm{d})$, and ADG $(\mathrm{kg} / \mathrm{d})$ were collected and assessed by individual animal (Tables 1 and 2). Additional information about the studies is available in Supplemental Tables S1 to S4 (https://doi.org/10.3168/jds.2018-15166).

Animals were separated into 2 breeds: Holstein (those with a Holstein pedigree greater than 87.5\%) and Holstein $\times$ Gyr (those with a Holstein pedigree lower than $87.5 \%$ ). Based on this categorization, the database comprised 113 Holstein calves and 97 Holstein $\times$ Gyr calves (Table 1).

\section{Slaughter and Samplings}

For all studies, the comparative slaughter technique was used to estimate body composition of each animal. Briefly, a group of animals (baseline group) were slaughtered at the beginning of the experiment to estimate initial EBW and initial mineral composition of the animals that remained in the studies. From the 210 animals, 30 animals were assigned to the baseline group. Before slaughter, all animals were allowed water for $16 \mathrm{~h}$ to obtain the shrunk BW (SBW). At the end of the trials, all animals were then slaughtered via captive bolt stunning followed by exsanguination. After exsanguination, the digesta was removed and discarded. The heart, lungs, liver, spleen, kidneys, fat around the kidney, pelvis, diaphragm, mesentery, tails, trimmings, and washed gastrointestinal tract were weighed. These values were added to the other portions of the body (i.e., carcasses, head, hide, limbs, and blood) to determine the EBW.

The rumen, reticulum, omasum, abomasum, small and large intestines, mesentery, liver, heart, kidneys, lung, tongue, spleen, diaphragm, esophagus, trachea, and reproductive tract were homogenized in an industrial grinder (model B5K326AG204; RefereInox, Chapecó, SC, Brazil) for $20 \mathrm{~min}$. After removing the hide, the head and limbs were also ground in a bone crusher (model TOL10, Luiz Nasciutti SA Industry and Trade, Araguari, MG, Brazil) for $20 \mathrm{~min}$.

The hide was sampled in 2 parts to represent the shoulder, 3 parts to represent the dorsal line, 2 parts to represent the ventral line, 2 parts to represent the rear, 1 part to represent each foot, and 1 part to represent the head, which altogether represented the entire hide. A composite sample of noncarcass components was 
constructed in which blood, head, limbs, hide, organs, and viscera were sampled based on the relative proportions of each component after summing all weights of the components.

After slaughter, the carcasses of each animal were split into 2 half carcasses, which were chilled at $4^{\circ} \mathrm{C}$ for $18 \mathrm{~h}$. After the 18-h period, all cooled half carcasses were weighed and the right half carcass was ground (model TOL10, Luiz Nasciutti SA Industry and Trade) for $20 \mathrm{~min}$ in an industrial grinder (the carcass components samples). The noncarcass and carcass samples were lyophilized (Liotop L510/ 220V, Liotop, São Carlos, SP, Brazil) and ground in a ball mill for mineral analyses.

\section{Chemical Analysis}

Samples of feeds and body components were evaluated for mineral content by digestion in nitroperchloric acid according to the INCT-CA M-004/1 method as described by Detmann et al. (2012). After obtaining the mineral solution, dilutions were made for the quantification of macromineral concentrations. The concentrations of $\mathrm{Ca}$ and $\mathrm{Mg}$ were quantified by atomic absorption spectrometry (GBC Avanta Sigma, GBC Scientific Equipment, Hampshire, IL; method 968.08; AOAC International, 2000). The $\mathrm{K}$ and Na concentrations were quantified by flame emission spectrometry (Corning 400, Corning, NY; method 985.35; AOAC International, 2000). The $\mathrm{P}$ contents were performed by reduction of the P-molybdate complex with ascorbic acid, and the readings were performed in a calorimeter spectrophotometer (method 965.17; AOAC International, 2000).

\section{Calculations}

The linear model was used to estimate EBW from SBW as follows:

$$
\mathrm{EBW}(\mathrm{kg})=\beta_{0}+\beta_{1} \times \mathrm{SBW}(\mathrm{kg}),
$$

where $\beta_{0}$ and $\beta_{1}$ are regression parameters. Moreover, the linear model was used to estimate EBG from ADG as follows:

$$
\operatorname{EBG}(\mathrm{kg} / \mathrm{d})=\beta_{0}+\beta_{1} \times \mathrm{ADG}(\mathrm{kg} / \mathrm{d}),
$$

where $\beta_{0}$ and $\beta_{1}$ are regression parameters.

Net requirements for maintenance and RC of each mineral were calculated by the regression between the RM and MI. The intercept $\left(\beta_{0}\right)$ of this model was considered as the net requirement for maintenance and represents mineral loss of each mineral when intake is 
Table 2. Descriptive statistics of data used to estimate the macromineral requirements

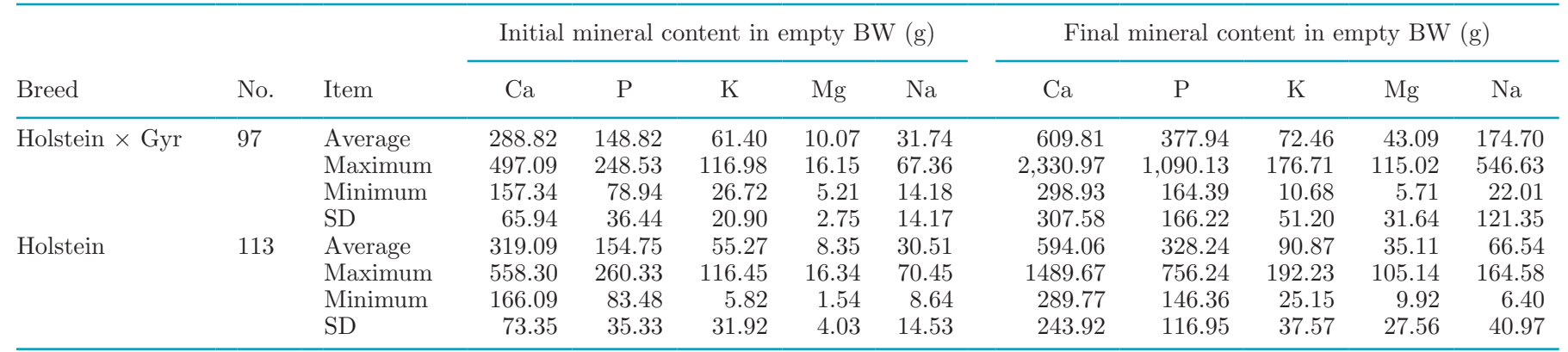

zero. Additionally, the slope $\left(\beta_{1}\right)$ was considered to be RC as follows (adapted from Ferrell and Jenkins, 1998):

$$
\begin{gathered}
\mathrm{RM}(\mathrm{mg} / \mathrm{kg} \text { of EBW per day })=\beta_{0}+\beta_{1} \\
\times \mathrm{MI}(\mathrm{mg} / \mathrm{kg} \text { of EBW per day }),
\end{gathered}
$$

where $\beta_{0}$ and $\beta_{1}$ are regression parameters; $\beta_{0}$ is the net mineral requirements for maintenance, and $\beta_{1}$ is the $\mathrm{RC}$ of each mineral.

To estimate the net mineral requirements for gain, the body mineral content as a function of the $\log 10$ EBW was estimated by regression according to the allometric model proposed by ARC (1980):

$$
\mathrm{Y}(\mathrm{g})=\beta_{0}+\beta_{1} \times \log \mathrm{EBW}(\mathrm{kg}),
$$

where $\mathrm{Y}$ is the $\log$ of the body mineral content, which might be $\mathrm{Ca}, \mathrm{P}, \mathrm{K}, \mathrm{Mg}$, or $\mathrm{Na}$; and $\beta_{0}$ and $\beta_{1}$ are regression parameters.

From the estimated parameters, the net mineral requirements for gain were determined by the first derivative of Equation 4 multiplied by EBG according to the following model (ARC, 1980):

$$
\begin{aligned}
& \operatorname{NMg}(\mathrm{mg} / \mathrm{d})= \\
& \beta_{1} \times 10^{\beta_{0}} \times \mathrm{EBW}(\mathrm{kg})^{\beta_{1}-1} \times \mathrm{EBG}(\mathrm{kg} / \mathrm{d}),
\end{aligned}
$$

where $\mathrm{NMg}=$ net requirement of the mineral for gain, which might be $\mathrm{Ca}, \mathrm{P}, \mathrm{K}, \mathrm{Na}$, or $\mathrm{Mg}$; and $\beta_{0}$ and $\beta_{1}$ are regression parameters. The minerals dietary requirements were described as the daily amount of a mineral that the animal must ingest to achieve a predefined level of performance (BR-CORTE, 2016) and were calculated using the sum of the net requirements for maintenance and gain divided by the coefficient of retention.

\section{Statistical Procedures}

The parameters of the linear models were estimated using the MIXED procedure of SAS (version 9.3; SAS
Institute Inc., Cary, NC). As the data comprised observations from different studies, it was necessary to quantify the variance associated with each of the studies. Therefore, each experiment was considered as a random sample of a large population and the data were analyzed following the technique described by St-Pierre (2001) for meta-analysis. The breed effect was tested on the intercept and slope of each model (Equations 1 to 4 ), and differences were declared when $P<0.05$. Observations with residues higher than $|2.5|$ were considered outliers and excluded from the database. From the total, 9, 9, 11, 15, and 8 animals were removed for $\mathrm{Ca}, \mathrm{K}, \mathrm{P}, \mathrm{Mg}$, and $\mathrm{Na}$ analysis, respectively.

\section{RESULTS AND DISCUSSION}

\section{$E B W$ and $E B G$}

A breed effect was not observed on the intercept $(P$ $=0.10)$ and the slope $(P=0.08)$ of the relationship between SBW and EBW. Additionally, the intercept did not differ from zero $(P=0.07)$ and the equation was adjusted as follows $\left(\mathrm{MSE}=4.412 ; \mathrm{R}^{2}=0.928\right)$ :

$$
\mathrm{EBW}(\mathrm{kg})=0.89 \times \mathrm{SBW}(\mathrm{kg}) .
$$

A breed effect was also not observed on the intercept $(P=0.70)$ and slope $(P=0.64)$ of the relationship between EBG and ADG. In addition, the regression intercept did not differ from zero $(P=0.34)$; consequently, the regression was readjusted without the inclusion of the intercept $\left(\mathrm{MSE}=0.054 ; \mathrm{R}^{2}=0.952\right)$ :

$$
\operatorname{EBG}(\mathrm{kg} / \mathrm{d})=0.91 \times \operatorname{ADG}(\mathrm{kg} / \mathrm{d}) .
$$

For all requirements, Equation 6 was used to convert EBW to BW and thus calculate requirements of the minerals in milligrams per kilogram of $\mathrm{BW}$ per day when necessary in order to compare studies that present requirements as milligrams per kilogram of BW per day. 
Table 3. Parameters of the equations to estimate the net maintenance requirements $\left(\beta_{0}\right)$ and the retention coefficients $\left(\beta_{1}\right)$ of the macrominerals ${ }^{1}$

\begin{tabular}{lcrrrrrrr}
\hline Mineral & \multicolumn{1}{c}{$\beta_{0}$} & SEE & $P$-value & & $\beta_{1}$ & SEE & $P$-value & RMSE $^{3}$ \\
\hline $\mathrm{Ca}$ & -12.73 & 22.359 & 0.739 & 0.7318 & 0.200 & 0.452 & 62.294 \\
$\mathrm{P}$ & -11.81 & 13.339 & 0.572 & 0.6520 & 0.154 & 0.633 & 0.189 \\
$\mathrm{~K}$ & -20.28 & 9.021 & 0.495 & 0.1316 & 0.024 & 0.404 & 0.334 \\
$\mathrm{Mg}$ & -3.50 & 0.970 & 0.137 & 0.2955 & 0.048 & 0.087 & 10.329 \\
$\mathrm{Na}$ & -6.37 & 4.892 & 0.377 & 0.2428 & 0.144 & 0.054 & 0.360 \\
\hline
\end{tabular}

${ }^{1} \mathrm{SEE}=$ standard error of parameter estimate; RMSE $=$ root mean squared error; $\mathrm{R}^{2}=$ adjusted coefficient of determination.

${ }^{2}$ Effect of breed on the net requirement of maintenance.

${ }^{3}$ Effect of breed on the retention coefficient.

\section{Mineral Requirements}

The effect of breed was not observed on net requirements for maintenance and gain or on the predicted $\mathrm{RC}$ $(P>0.05)$. Consequently, dietary mineral requirements were considered similar for both breeds. Similarly, a breed effect was not observed on BW, ADG, MI, RM, and final body mineral content $(P>0.05$; Table 1$)$. The effect of breed might not have been observed because the study used similar diets, management, and climate conditions and the same methodology for estimating MI and RM and for mineral analysis. We suspect that these effects are more likely to affect macromineral requirements (Underwood, 1981) compared with breed effects. However, BR-CORTE (2016) reported differences in mineral requirements for gain of different beef cattle breeds with an average BW of $315 \mathrm{~kg}$. It is likely that mineral requirement differences might be expressed in other phases of gain but not in preweaned dairy calves. Therefore, it is consistent to recommend the estimates obtained in this study for both breeds (Holstein and Holstein $\times$ Gyr $)$ in preweaned dairy calves up to 100 $\mathrm{kg}$ of BW.

\section{Ca}

Requirements for Maintenance. The obtained net $\mathrm{Ca}$ requirements for maintenance were $12.72 \mathrm{mg} /$ $\mathrm{kg}$ of EBW per day (Table 3) or $11.32 \mathrm{mg} / \mathrm{kg}$ of BW per day. In comparative terms, BR-CORTE (2016) suggested the value of $11.70 \mathrm{mg} / \mathrm{kg}$ of $\mathrm{BW}$ per day for Zebu beef cattle (Nellore and crossbreed) in all stages (steers, heifers, and bulls) raised under tropical conditions, whereas NRC (2001) suggested a value of $15.40 \mathrm{mg} / \mathrm{kg}$ of BW per day for Holstein calves raised in temperate climate conditions. However, Hansard et al. (1954) recommended $14.40 \mathrm{mg} / \mathrm{kg}$ of $\mathrm{BW}$ per day for Hereford calves at $30 \mathrm{~d}$ of age. According to INRA (2007), considering a calf with $67 \mathrm{~kg}$ of BW and a DMI of $1.1 \mathrm{~kg} / \mathrm{d}$ (the values of BW and DMI were the mean values obtained in the present study), the net Ca requirement for maintenance is $18.89 \mathrm{mg} / \mathrm{kg}$ of
BW per day. The recommendation of this study was close to that of BR-CORTE (2016); however, compared with the estimates of NRC (2001), it was $26.5 \%$ lower. The net Ca requirements for maintenance of Holstein $\times$ Gyr and Holstein calves were close to those of Zebu cattle (Nellore purebred and crossbred cattle) raised under tropical conditions, indicating that this difference might be associated with the effect of climatic conditions. We speculated that Holstein animals raised under tropical conditions have adapted to these climatic conditions, which might be associated with a reduction in the net requirement of $\mathrm{Ca}$ for maintenance. However, no published data have specifically evaluated the effect of climate on net $\mathrm{Ca}$ requirements for maintenance. Furthermore, the methodology used to calculate the maintenance requirements for $\mathrm{Ca}$ in the current study was different from the methodology used by Hansard et al. (1954) and NRC (2001) and might have contributed to the observed differences in Ca maintenance requirements.

$R C$. The $\mathrm{RC}$ of Ca obtained in this study was $73.18 \%$ (Table 3); this is higher than that of BR-CORTE (2016), which was reported as $56.8 \%$ for Zebu beef cattle. Challa and Braithwaite (1989) reported an RC for Ca of $83 \%$ for 138-kg calves, and Yuangklang et al. (2004) reported an absorption coefficient for Ca of $95 \%$ for 47 $\mathrm{kg}$ calves. NRC (2001) and AFRC (1991) recommended values of 70 and $68 \%$, respectively, as absorption coefficients for Ca. However, these studies used an absorption coefficient, neglecting Ca losses via urine. Costa e Silva et al. (2015), studying Nellore bulls, steers, and heifers, reported Ca losses of up to $3.8 \%$ in the urine. Thus, neglecting Ca losses via urine can result in an overestimation of the true RC. However, the variation in $\mathrm{RC}$ of $\mathrm{Ca}$ between the present study and others can be explained by the fact that the absorption coefficient of $\mathrm{Ca}$ is not a fixed value and is influenced by physiological states (Allen, 1982). In this sense, Ca can be absorbed in the intestine by 2 routes: transcellular and paracellular (Bronner, 1987). The transcellular route is saturable and subject to physiological and nutritional regulation via vitamin $\mathrm{D}$, whereas the paracellular route 


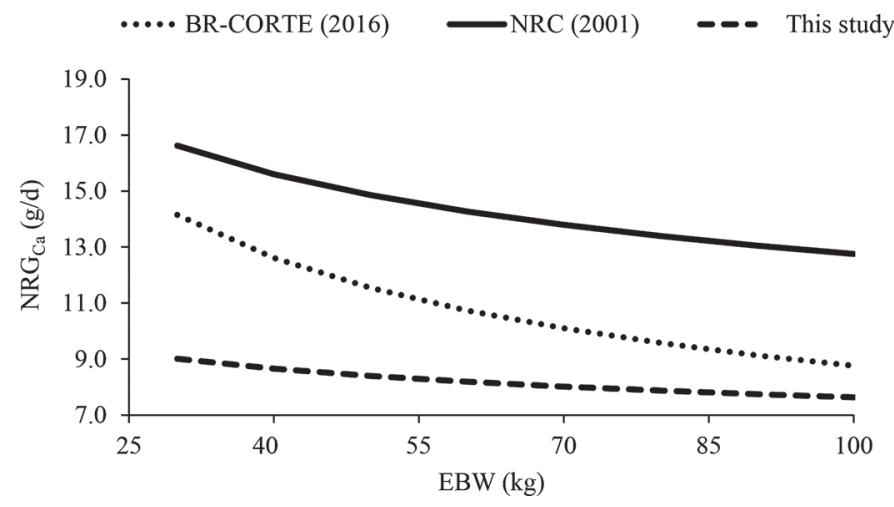

Figure 1. Net Ca requirements for growth $\left(\mathrm{NRG}_{\mathrm{Ca}}, \mathrm{g} / \mathrm{d}\right.$; tissue accrual requirement) proposed by this study, BR-CORTE (2016), and NRC (2001) considering empty BW (EBW) equal to $1.0 \mathrm{~kg} / \mathrm{d}$. BRCORTE (2016) equation $(\mathrm{g} / \mathrm{d}): \mathrm{NRG}_{\mathrm{Ca}}=\mathrm{EBG} \times\left(54.8 \times \mathrm{EBW}^{-0.3981}\right)$; $\mathrm{NRC}(2001)$ equation $(\mathrm{g} / \mathrm{d}): \mathrm{NRG}_{\mathrm{Ca}}=9.83 \times \mathrm{MW}^{0.22} \times \mathrm{BW}^{-0.22} \times$ ADG; this study: $\mathrm{NRG}_{\mathrm{Ca}}=14.402 \times \mathrm{EBW}^{-0.139} \times \mathrm{EBG}$. $\mathrm{MW}=\mathrm{ex}-$ pected mature live BW $(\mathrm{kg}) ; \mathrm{EBG}=$ empty body gain $(\mathrm{kg} / \mathrm{d})$. EBW given in $\mathrm{kg}, \mathrm{BW}$ given in $\mathrm{kg}$, and ADG given in $\mathrm{kg} / \mathrm{d}$.

is nonsaturable and essentially independent of nutritional and physiological regulation. Thus, a reduction in plasma $\mathrm{Ca}$ concentration activates the parathyroid hormone (1,25-dihydroxyvitamin D) in plasma, which stimulates increased intestinal $\mathrm{Ca}$ absorption via the active transcellular route (Fairweather-Tait and Hurrell, 1996), which might affect Ca RC. Therefore, it is important to highlight that the RC suggested in this study is recommended for animals fed close to their requirements.

In addition, the variation in $\mathrm{RC}$ of $\mathrm{Ca}$ among the present study and others might be attributed to animal age, where young animals (suckling calves) have higher Ca absorption compared with adult animals due to milk Ca bioavailability (Yuangklang et al., 2004; BR-CORTE, 2016). Hansard et al. (1954) reported a reduction in absorption of Ca from $97 \%$ to $38 \%$ with an increase from 1 to 6 mo of age or with a BW increase from $66 \mathrm{~kg}$ to $178 \mathrm{~kg}$. This could be attributed to higher diet digestibility during the preweaning phase, where milk is the main component of the diet, and to the reduced level of the $\mathrm{Ca}$ in the diet in greater $\mathrm{BW}$.
As animals grow, there is a reduction in the proportion of bone to muscle in the body (Paulino et al., 1999), considering that approximately $99 \%$ of $\mathrm{Ca}$ is present in the bone (AFRC, 1991; NRC, 2001). Therefore, an $\mathrm{RC}$ of $73.18 \%$ suggested in this study is adequate for Holstein and Holstein $\times$ Gyr preweaning dairy calves.

Requirements for Gain. The parameters of the regression of Ca content in EBW can be found in Table 4 , and the net $\mathrm{Ca}$ requirements for gain were estimated using the following equation:

$$
\begin{aligned}
\mathrm{NRG}_{\mathrm{Ca}}= & 14.402 \times \mathrm{EBW}(\mathrm{kg})^{-0.139} \\
& \times \mathrm{EBG}(\mathrm{kg} / \mathrm{d}),
\end{aligned}
$$

where $\mathrm{NRG}_{\mathrm{ca}}=$ net Ca requirement for growth.

The net $\mathrm{Ca}$ requirements for gain proposed in this study were lower than those reported by NRC (2001) and BR-CORTE (2016) considering a calf with BW between 40 and $100 \mathrm{~kg}$ and ADG of $1 \mathrm{~kg} / \mathrm{d}$ (Figure 1). BR-CORTE (2016) used data from Nelore calves up to $180 \mathrm{~d}$ of age for estimates of $\mathrm{Ca}$ net requirements for gain, whereas in the present study the average age was $55 \pm 17.7$ d. NRC (2001) requirements estimates for gain were based on the estimates of AFRC (1991), which were determined in temperate climate conditions with animals from the Bos taurus breeds with greater BW. The use of animals with greater BW might affect the estimates of Ca requirements for calves because $99 \%$ of $\mathrm{Ca}$ is found in bones. Heavier animals have a lower proportion of bone in the body (Paulino et al., 1999), causing a bias in the estimates when extrapolated for lighter animals.

Dietary Requirements. The dietary requirements of Ca for this study, for BR-CORTE (2016), and for NRC (2001) are shown in Table 5. A decrease in Ca requirements when $\mathrm{BW}$ increases is observed due to a lower proportion of this mineral in the body relative to other nonbone tissues (AFRC, 1991; Paulino et al., 1999). Moreover, the dietary Ca requirement is lower in this study compared with NRC (2001) and BRCORTE (2016). As previously discussed, the estimates of these studies were obtained with heavier and older

Table 4. Parameters $\left(\beta_{0}\right.$ and $\left.\beta_{1}\right)$ of the equations to estimate the logarithm of the content of $\mathrm{Ca}, \mathrm{P}, \mathrm{K}, \mathrm{Mg}$, and $\mathrm{Na}$ in the body ${ }^{1}$

\begin{tabular}{lcccccc}
\hline Mineral & $\beta_{0}$ & SEE & $\beta_{1}$ & SEE & RMSE & $\mathrm{R}^{2}$ \\
\hline $\mathrm{Ca}$ & 1.223 & 0.166 & 0.862 & 0.097 & 0.106 & 0.436 \\
$\mathrm{P}$ & 0.779 & 0.205 & 0.973 & 0.117 & 0.109 & 0.499 \\
$\mathrm{~K}$ & 0.075 & 0.128 & 0.958 & 0.122 & 0.079 & 0.650 \\
$\mathrm{Mg}$ & -0.203 & 0.183 & 0.964 & 0.067 & 0.094 & 0.630 \\
$\mathrm{Na}$ & 0.198 & 0.250 & 0.955 & 0.095 & 0.082 & 0.659 \\
\hline
\end{tabular}

${ }^{1} \mathrm{SEE}=$ standard error of parameter estimate; RMSE $=$ root mean squared error; $\mathrm{R}^{2}=$ adjusted coefficient of determination. 
Table 5. Dietary requirements $(\mathrm{g} / \mathrm{d})$ of $\mathrm{Ca}, \mathrm{P}, \mathrm{K}, \mathrm{Mg}$, and $\mathrm{Na}$ based on the estimates proposed by this study, BR-CORTE (2016), and NRC (2001) for different empty BW (EBW; kg) and empty body gain (EBG; kg/d)

\begin{tabular}{|c|c|c|c|c|c|c|c|}
\hline \multirow[b]{3}{*}{ Mineral } & \multirow[b]{3}{*}{ EBW } & \multicolumn{6}{|c|}{$\mathrm{EBG}$} \\
\hline & & \multicolumn{2}{|c|}{ Present study } & \multicolumn{2}{|c|}{ BR-CORTE (2016) } & \multicolumn{2}{|c|}{ NRC (2001) } \\
\hline & & 0.50 & 1.00 & 0.50 & 1.00 & 0.50 & 1.00 \\
\hline $\mathrm{Ca}$ & 40 & 6.61 & 12.53 & 12.07 & 23.18 & 12.13 & 23.28 \\
\hline $\mathrm{P}$ & 40 & 4.78 & 8.81 & 6.38 & 11.91 & 8.23 & 13.64 \\
\hline K & 40 & 1.47 & 2 & 3.29 & 4.52 & 2.83 & 3.76 \\
\hline $\mathrm{Mg}$ & 40 & 1.36 & 2.25 & 1.24 & 1.76 & 2.18 & 3.56 \\
\hline $\mathrm{Na}$ & 40 & 3.58 & 6.1 & 2.22 & 3.72 & 1.56 & 2.38 \\
\hline $\mathrm{Ca}$ & 70 & 6.7 & 12.18 & 10.56 & 19.45 & 11.58 & 21.44 \\
\hline $\mathrm{P}$ & 70 & 5.29 & 9.26 & 6.89 & 12.3 & 8.4 & 13.18 \\
\hline K & 70 & 2.15 & 2.67 & 4.76 & 5.95 & 4.25 & 5.18 \\
\hline $\mathrm{Mg}$ & 70 & 1.7 & 2.58 & 1.75 & 2.27 & 2.77 & 4.16 \\
\hline $\mathrm{Na}$ & 70 & 4.24 & 6.65 & 2.73 & 4.21 & 2.12 & 2.94 \\
\hline $\mathrm{Ca}$ & 100 & 6.95 & 12.17 & 10.09 & 17.8 & 11.58 & 20.69 \\
\hline $\mathrm{P}$ & 100 & 5.81 & 9.74 & 7.43 & 12.78 & 8.83 & 13.25 \\
\hline $\mathrm{K}$ & 100 & 2.83 & 3.35 & 6.24 & 7.4 & 5.67 & 6.6 \\
\hline $\mathrm{Mg}$ & 100 & 2.04 & 2.9 & 2.26 & 2.78 & 3.37 & 4.75 \\
\hline $\mathrm{Na}$ & 100 & 4.95 & 7.28 & 3.25 & 4.72 & 2.68 & 3.5 \\
\hline
\end{tabular}

animals and with different genetic composition. The higher Ca requirements recommended by these studies (NRC, 2001; BR-CORTE, 2016) might be contributing to high dietary $\mathrm{Ca}$ in the initial life phase, consequently increasing production costs and excretion of $\mathrm{Ca}$ into the environment.

\section{$P$}

Requirements for Maintenance. The net $\mathrm{P}$ requirements for maintenance obtained in this study were $11.81 \mathrm{mg} / \mathrm{kg}$ of EBW per day (Table 3) or $10.51 \mathrm{mg} /$ $\mathrm{kg}$ of $\mathrm{BW}$ per day. The observed value is lower than those reported by NRC (2001) and BR-CORTE (2016) of 16.00 and $13.50 \mathrm{mg} / \mathrm{kg}$ of BW per day, respectively, which is 34.30 and $22.14 \%$ greater than our estimates, respectively. According to INRA (2007), the net $\mathrm{P}$ requirement for maintenance is estimated to be 15.63 $\mathrm{mg} / \mathrm{kg}$ of BW per day. As was observed for Ca requirements, net $\mathrm{P}$ requirements for maintenance had lower estimates compared with the studies reported in the literature (NRC, 2001; INRA, 2007) and were closer to the values suggested by BR-CORTE (2016), indicating that climate might have an influence on this variable. The similar net requirements of $\mathrm{P}$ for maintenance of Zebu cattle (recommend by BR-CORTE, 2016) and Holstein $\times$ Gyr and Holstein calves (recommended by this study) raised under tropical conditions might indicate that Holstein animals can be acclimated to tropical conditions and consequently decrease net $\mathrm{P}$ requirements for maintenance. Nonetheless, the mechanisms of such adaptation need to be further investigated.
$R C$. The $\mathrm{RC}$ of $\mathrm{P}$ obtained in this study was $65.2 \%$ (Table 3). According to NRC (2001), the recommended $\mathrm{P}$ absorption coefficient for calves consuming only milk is $90 \%$. For animals with BW between 100 and $200 \mathrm{~kg}$, the value suggested by this council was $78 \%$. AFRC (1991) and Gueguen et al. (1989) recommended absorption coefficients of 58 and $60 \%$, respectively. It should be highlighted that these studies considered only absorption coefficient and neglected urinary $\mathrm{P}$ excretion, which might lead to a bias in the overall estimate (excretion of this mineral through the urine can reach $4.33 \%$ of P intake; Costa e Silva et al., 2015). The BR-CORTE (2016) council recommends an RC of $68 \%$, which is close to that reported in this study. Thus, urinary $\mathrm{P}$ losses should not be neglected, and we suggest an $\mathrm{RC}$ value of $65.2 \%$ for Holstein and Holstein $\times$ Gyr preweaning dairy calves.

Requirements for Gain. The parameters of the regression of $\mathrm{P}$ content in EBW can be found in Table 4 , and net $\mathrm{P}$ requirement for gain can be estimated using the following equation:

$$
\mathrm{NRG}_{\mathrm{P}}=5.849 \times \mathrm{EBW}(\mathrm{kg})^{-0.027} \times \mathrm{EBG}(\mathrm{kg} / \mathrm{d}),[9]
$$

where $\mathrm{NRG}_{\mathrm{P}}=$ net $\mathrm{P}$ requirement for gain.

The estimates for $\mathrm{P}$ requirements for gain were lower than those reported by NRC (2001) and BR-CORTE (2016) considering an animal with BW between 40 and $100 \mathrm{~kg}$ and ADG of $1 \mathrm{~kg} / \mathrm{d}$ (Figure 2). The net $\mathrm{P}$ requirements for gain proposed in this study, by BRCORTE (2016), and by NRC (2001) decreased as BW increased (Figure 2) due to a lower proportion of bone 


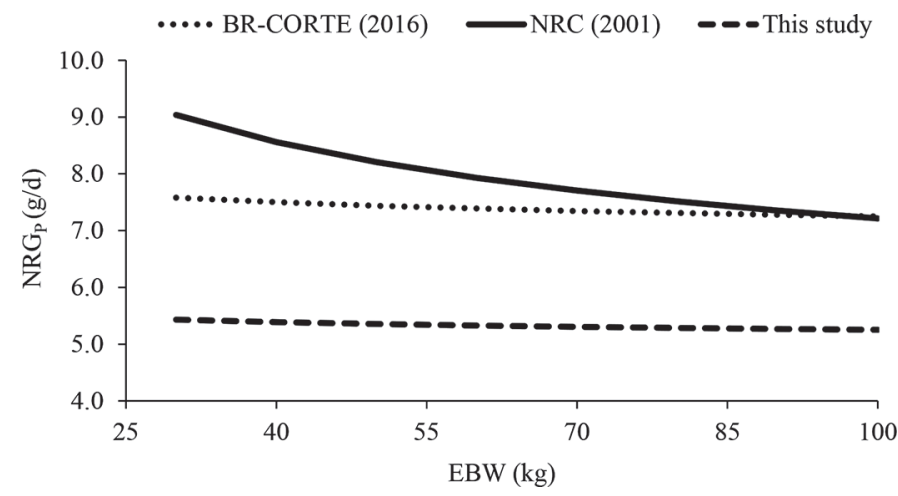

Figure 2. Net $\mathrm{P}$ requirements for growth $\left(\mathrm{NRG}_{\mathrm{P}}, \mathrm{g} / \mathrm{d}\right.$; tissue accrual requirement) proposed by this study, BR-CORTE (2016), and NRC (2001) considering empty BW (EBW) equal to $1.0 \mathrm{~kg} / \mathrm{d}$. BR-CORTE $(2016)$ equation $(\mathrm{g} / \mathrm{d}): \mathrm{NRG}_{\mathrm{P}}=\mathrm{EBG} \times\left(8.6 \times \mathrm{EBW}^{-0.0371}\right) ; \mathrm{NRC}$ $(2001)$ equation $(\mathrm{g} / \mathrm{d}): \mathrm{NRG}_{\mathrm{P}}=\left(1.2+4.635 \times \mathrm{MW}^{0.22}\right) \times\left(\mathrm{BW}^{-0.22}\right) \times$ ADG; this study: $\mathrm{NRG}_{\mathrm{P}}=5.849 \times \mathrm{EBW}^{-0.027} \times \mathrm{EBG}$. $\mathrm{MW}=\mathrm{ex}-$ pected mature live $\mathrm{BW}(\mathrm{kg}) ; \mathrm{EBG}=$ empty body gain $(\mathrm{kg} / \mathrm{d})$. EBW given in $\mathrm{kg}$, $\mathrm{BW}$ given in $\mathrm{kg}$, and $\mathrm{ADG}$ given in $\mathrm{kg} / \mathrm{d}$.

tissue in the body because $80 \%$ of $\mathrm{P}$ is found in bone tissue (Coelho da Silva, 1995). Thus, the estimates obtained with heavier animals as described in NRC (2001) and BR-CORTE (2016) might cause a bias when used for lighter animals, which might compromise animal performance or increase $\mathrm{P}$ excretion.

Dietary Requirements. Comparing the dietary $\mathrm{P}$ requirements (Table 5) proposed in this study with those of BR-CORTE (2016) and NRC (2001), our estimated requirements for calves with $\mathrm{BW}$ between 40 and $100 \mathrm{~kg}$ were 24.8 and $29.7 \%$ lower, respectively. Thus, lower P requirements for Holstein $\times$ Gyr and Holstein calves raised under tropical conditions are recommended compared with requirements for older beef cattle (bulls, heifers, and steers) raised in similar conditions or Holstein calves raised in temperate climate conditions.

It is important to balance $\mathrm{Ca}: \mathrm{P}$ ratio in diets for ruminants because both minerals act in synchrony with one another (ARC, 1980). ARC (1980) suggests that this ratio should be between $1: 1$ and $2: 1$ and that proportions outside this range might alter animals' requirement (ARC, 1980). The value obtained in this study for calves with BW between 40 and $100 \mathrm{~kg}$ was 1.36:1, which is within the range suggested by ARC (1980) and close to that suggested by BR-CORTE (2016) of 1.46:1 for Zebu and crossbred beef cattle.

K

Requirements for Maintenance. The net $\mathrm{K}$ requirements for maintenance obtained in this study were $20.28 \mathrm{mg}$ of $\mathrm{K} / \mathrm{kg}$ of EBW per day (Table 3 ) or 18.05 $\mathrm{mg}$ of $\mathrm{K} / \mathrm{kg}$ of BW per day. These estimates were lower than those reported by NRC (2001), INRA (2007), and BR-CORTE (2016) of 38.0, 105.0, and $23.5 \mathrm{mg}$ of $\mathrm{K} / \mathrm{kg}$ of $\mathrm{BW}$ per day, respectively. The estimates obtained in this study and in BR-CORTE (2016) were lower than those suggested by NRC (2001) and INRA (2007). Again, we highlight the similarity between the estimates obtained under tropical conditions, indicating that environment might affect $\mathrm{K}$ requirements for maintenance. Nevertheless, we could not find physiological mechanisms that could explain why $\mathrm{K}$ requirements for maintenance are reduced in warm environments.

$R C$. The RC of $\mathrm{K}$ obtained in this study was $13.1 \%$ (Table 3). This value is lower than the RC suggested by BR-CORTE (2016; 48.4\%). Nevertheless, BR-CORTE (2016) considers mineral retained calculated by the difference between MI and mineral losses via feces and urine. However, $\mathrm{K}$ can be excreted via other avenues, such as in saliva $(0.7 \mathrm{~g} / 100 \mathrm{~kg}$ of $\mathrm{BW})$ and sweat (1.1 $\mathrm{g} / \mathrm{d}$; ARC 1980). ARC (1980) and NRC (2001) use absorption coefficients of K of 100 and $90 \%$, respectively. However, it should be noted that these studies used absorption coefficient and not RC. Thus, data from the literature suggest that $30 \%$ of the $\mathrm{K}$ intake is excreted via urine (BR-CORTE, 2016).

Estimates of a K RC might have limitations because $\mathrm{K}$ is typically high in ruminant diets (Underwood and Suttle, 1999), and milk fed to calves contains on average $1.44 \mathrm{mg}$ of $\mathrm{K} / \mathrm{mL}$ (Gaucheron, 2005). We suggest that high $\mathrm{K}$ intake might be associated with an increase in $\mathrm{K}$ excretion via urine, which might yield a lower RC. Therefore, the low RC for $\mathrm{K}$ found in this study might be linked to the excess of $\mathrm{K}$ in the diet. Thus, the use of the low $\mathrm{RC}$ obtained in this study would produce a greater $\mathrm{K}$ requirement of preweaned dairy calves. Furthermore, the use of the RC obtained in this study can possibly increase excretion of $\mathrm{K}$ in the environment and increase production costs. Thus, we suggest the use of a $90 \%$ absorption coefficient recommended by NRC (2001) to calculate dietary K requirements of preweaned dairy calves.

Requirements for Gain. The parameters of the regression of $\mathrm{K}$ content in EBW can be found in Table 4 , and the net $\mathrm{K}$ requirement for gain can be estimated using the following equation:

$$
\begin{aligned}
\mathrm{NRG}_{\mathrm{K}}= & 1.140 \times \mathrm{EBW}(\mathrm{kg})^{-0.048} \\
& \times \mathrm{EBG}(\mathrm{kg} / \mathrm{d})
\end{aligned}
$$

where $\mathrm{NRG}_{\mathrm{K}}=$ net $\mathrm{K}$ requirement for gain.

The estimated net $\mathrm{K}$ requirements for gain (Figure 3 ) in this study were 17.0 and $42.7 \%$ lower than those reported by BR-CORTE (2016) and NRC (2001), re- 
spectively, for calves with BW between 40 and $100 \mathrm{~kg}$ and ADG of $1 \mathrm{~kg} / \mathrm{d}$. However, the estimates of BRCORTE (2016) were generated with Nellore calves up to $180 \mathrm{~d}$ of age and $200 \mathrm{~kg}$ of BW. The NRC (2001) $\mathrm{K}$ recommendations are for animals with BW between 150 and $500 \mathrm{~kg}$ and not for preweaned calves (Gueguen et al., 1989) and thus should be used with caution when formulating $\mathrm{K}$ requirements for preweaned calves.

Dietary Requirements. The dietary requirements of $\mathrm{K}$ were 47 and $55 \%$ lower than those reported by NRC (2001) and BR-CORTE (2016), respectively (Table 5), for calves with BW between 40 and $100 \mathrm{~kg}$. When calculating the dietary requirements for $\mathrm{K}$, the absorption coefficient suggested by NRC (2001) was used, as discussed previously. It is worth noting that $\mathrm{K}$ requirements can be satisfied with milk supply only.

\section{$M g$}

Requirements for Maintenance. The net $\mathrm{Mg}$ requirements for maintenance obtained in this study were $3.50 \mathrm{mg}$ of $\mathrm{Mg} / \mathrm{kg}$ of EBW per day (Table 3), or $3.11 \mathrm{mg}$ of $\mathrm{Mg} / \mathrm{kg}$ of $\mathrm{BW}$ per day. These values are lower than those reported by BR-CORTE (2016) and INRA (2007), which suggest values of 5.90 and $7.0 \mathrm{mg}$ of $\mathrm{Mg} / \mathrm{kg}$ of $\mathrm{BW}$ per day, respectively. However, the value of this study was close to that recommended by NRC (2001) and ARC (1980) of $3.0 \mathrm{mg}$ of $\mathrm{Mg} / \mathrm{kg}$ of $\mathrm{BW}$ per day for animals with BW of $100 \mathrm{~kg}$. These differences might be linked to the fact that BR-CORTE (2016) used heavier animals (BW of $302 \mathrm{~kg}$ ) than those used in the current study (BW of $59.9 \mathrm{~kg}$ ).

$R C$. We observed an $\mathrm{RC}$ for $\mathrm{Mg}$ of $29.5 \%$ (Table 3 ), which is lower than that suggested by BR-CORTE (2016) of $35.5 \%$. The value obtained in this study is higher than that in NRC (2001), which uses an absorption coefficient of $16 \%$. The RC recommendation in this study was close to that of BR-CORTE (2016), indicating that, as we observed for other minerals, climate might have some effect on mineral metabolism because the NRC (2001) data were obtained in temperate climate conditions and the values of this study and BR-CORTE (2016) were obtained from animals housed under tropical conditions. In addition, NRC (2001) recommendations were based on heavier and adult ruminant animals, whereas calves are physiologically close to monogastrics, which have absorption coefficients between $52.0 \%$ for poultry (Shastak and Rodehutscord, 2015) and $83.1 \%$ for swine (Kiefer et al., 2012).

Requirements for Gain. The parameters of the regression of $\mathrm{Mg}$ content in EBW can be found in Table 4 , and the net $\mathrm{Mg}$ requirement for gain can be estimated using the following equation:

$$
\begin{aligned}
\mathrm{NRG}_{\mathrm{Mg}}= & 0.603 \times \mathrm{EBW}(\mathrm{kg})^{-0.036} \\
& \times \mathrm{EBG}(\mathrm{kg} / \mathrm{d})
\end{aligned}
$$

where $\mathrm{NRG}_{\mathrm{Mg}}=$ net $\mathrm{K}$ requirement for growth.

The net $\mathrm{Mg}$ requirements for gain is shown in Figure 4. The net $\mathrm{Mg}$ requirements of this study were higher than those of BR-CORTE (2016) and NRC (2001) considering calves with BW between 40 and $100 \mathrm{~kg}$ and ADG of $1 \mathrm{~kg} / \mathrm{d}$. As stated before, the estimates of BR-CORTE (2016) were generated with Nellore calves that were $200 \mathrm{~kg}$ of $\mathrm{BW}$. This difference might be associated with a lower $\mathrm{Mg}$ requirement because $70 \%$ of the $\mathrm{Mg}$ in the body is located in bones (BR-CORTE, 2016), and a reduction in the proportion of bone tissue in the body occurs with an increase in BW (Paulino et al., 1999). NRC (2001) recommended a fixed value of $0.45 \mathrm{~g}$ of $\mathrm{Mg} / \mathrm{kg}$ of ADG regardless of BW and feeding, underestimating the $\mathrm{Mg}$ requirements for preweaned dairy calves. Providing insufficient amounts of $\mathrm{Mg}$ in diet might compromise animal performance because $\mathrm{Mg}$ is a major intracellular cation and is necessary as a cofactor for enzymatic reactions that are vital to many major metabolic pathways in the body (Goff, 2017).

Dietary Requirements. The dietary requirements of $\mathrm{Mg}$ in this study were $17.0 \%$ higher than those reported by BR-CORTE (2016) and 37.6\% lower than those reported by NRC (2001; Table 5). The difference in $\mathrm{Mg}$ dietary requirements between this study and those proposed by BR-CORTE (2016) might be associated with different BW used in the estimates. BR-CORTE (2016) used animals with higher BW and therefore a lower proportion of bone tissue in the body (Paulino et al., 1999). However, the main difference

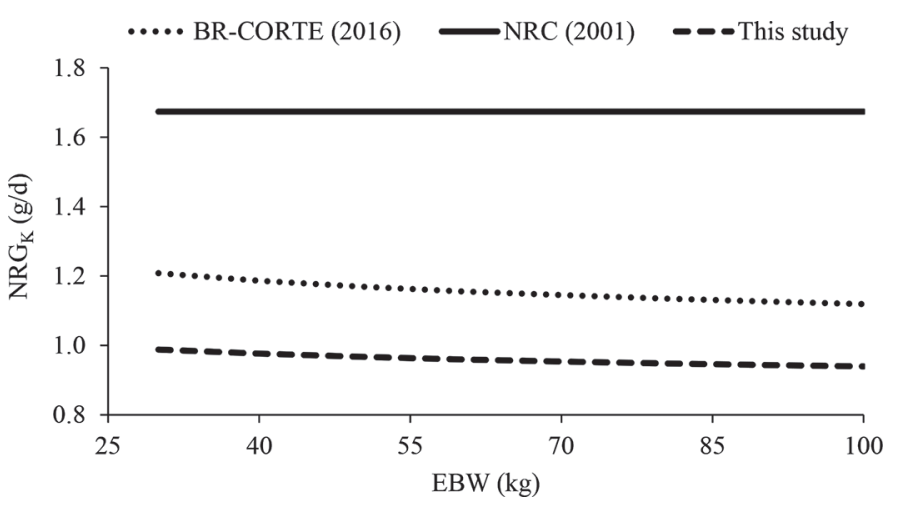

Figure 3. Net K requirements for growth $\left(\mathrm{NRG}_{\mathrm{K}} ; \mathrm{g} / \mathrm{d}\right.$; tissue accrual requirement) proposed by this study, BR-CORTE (2016), and NRC (2001) considering empty BW (EBW) equal to $1.0 \mathrm{~kg} / \mathrm{d}$. BRCORTE $(2016)$ equation $(\mathrm{g} / \mathrm{d}): \mathrm{NRG}_{\mathrm{K}}=\mathrm{EBG} \times(1.5 \times \mathrm{EBW})^{(-0.0636)}$; NRC $(2001)$ equation $(\mathrm{g} / \mathrm{d}): \mathrm{NRG}_{\mathrm{K}}=1.6 \times \mathrm{ADG}$; this study: $\mathrm{NRG}_{\mathrm{K}}$ $=1.140 \times \mathrm{EBW}^{-0.048} \times \mathrm{EBG} . \mathrm{EBG}=$ empty body gain $(\mathrm{kg} / \mathrm{d}) . \mathrm{EBW}$ given in $\mathrm{kg}, \mathrm{BW}$ given in $\mathrm{kg}$, and $\mathrm{ADG}$ given in $\mathrm{kg} / \mathrm{d}$. 
between the current study and NRC (2001) can be associated with the low absorption coefficient used by NRC (2001) compared with the absorption coefficient used in the current study.

\section{$\mathrm{Na}$}

Requirements for Maintenance. The net Na requirements for maintenance were $6.37 \mathrm{mg} / \mathrm{kg}$ of EBW per day (Table 3) or $5.67 \mathrm{mg}$ of $\mathrm{Na} / \mathrm{kg}$ of $\mathrm{BW}$ per day, which is close to the requirements suggested by BR-CORTE (2016) of $6.30 \mathrm{mg}$ of $\mathrm{Na} / \mathrm{kg}$ of BW per day and lower than that suggested by NRC (2001) and INRA (2007) of $15 \mathrm{mg}$ of $\mathrm{Na} / \mathrm{kg}$ of BW per day. The similar requirements between BR-CORTE (2016) and this study indicate that there is a similarity in Na net requirements for maintenance between animals raised in tropical conditions and animals raised in temperate conditions.

$R C$. The $\mathrm{RC}$ of $\mathrm{Na}$ was $24.28 \%$ (Table 3), which was lower than that suggested by BR-CORTE (2016) of $37.10 \%$. However, our study considered retained $\mathrm{Na}$ as that measured by directly quantifying the animal's body Na content, whereas the estimates of BR-CORTE (2016) were calculated by the difference between MI and mineral excretion via feces and urine. Thus, BRCORTE (2016) did not account for losses by saliva. Salivary sodium is expected to be almost $100 \%$ reabsorbed in the gastrointestinal tract; however, Aitken (1976) reported that nonacclimatized cattle in tropical conditions might lose up to $1.4 \mathrm{~g}$ of Na/d for each 100 $\mathrm{kg}$ of BW, which might explain, at least in part, our results. NRC (2001) recommends the value of $90 \%$ of $\mathrm{Na}$

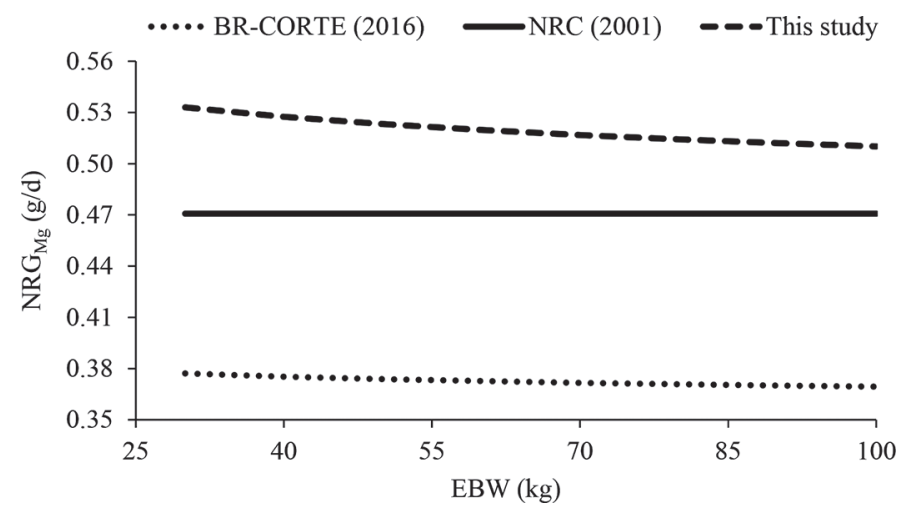

Figure 4. Net $\mathrm{Mg}$ requirements for growth $\left(\mathrm{NRG}_{\mathrm{Mg}} ; \mathrm{g} / \mathrm{d}\right.$; tissue accrual requirement) proposed by the present study, BR-CORTE (2016), and NRC (2001) considering empty BW $(\mathrm{EBW})=1.0 \mathrm{~kg} / \mathrm{d} . \mathrm{BR}-$ CORTE $(2016)$ equation $(\mathrm{g} / \mathrm{d}): \mathrm{NRG}_{\mathrm{Mg}}=\mathrm{EBG} \times\left(0.4 \times \mathrm{EBW}^{-0.0173}\right)$; $\mathrm{NRC}(2001)$ equation $(\mathrm{g} / \mathrm{d}): \mathrm{NRG}_{\mathrm{Mg}}=0.45 \times \mathrm{ADG}$; this study: $\mathrm{NRG}_{\mathrm{Mg}}$ $=0.603 \times \mathrm{EBW}^{-0.036} \times \mathrm{EBG} . \mathrm{EBG}=$ empty body gain $(\mathrm{kg} / \mathrm{d}) . \mathrm{EBW}$ given in $\mathrm{kg}$, $\mathrm{BW}$ given in $\mathrm{kg}$, and $\mathrm{ADG}$ given in $\mathrm{kg} / \mathrm{d}$. absorption coefficient and does not account for losses through saliva and urine, which are, on average, $38.6 \%$ of Na intake (Costa e Silva et al., 2015). Nevertheless, even considering $\mathrm{Na}$ losses via saliva and urine, our RC was much lower than the NRC (2001) absorption coefficient, suggesting that further studies are still necessary to fully understand $\mathrm{Na}$ retention in preweaned dairy calves.

Requirements for Gain. The parameters of the regression of Na content in EBW can be found in Table 4 , and net $\mathrm{Na}$ requirement for gain can be estimated using the following equation:

$$
\begin{aligned}
\mathrm{NRG}_{\mathrm{Na}}= & 1.508 \times \mathrm{EBW}(\mathrm{kg})^{-0.045} \\
& \times \mathrm{EBG}(\mathrm{kg} / \mathrm{d})
\end{aligned}
$$

where $\mathrm{NRG}_{\mathrm{Na}}=$ net $\mathrm{Na}$ requirement for growth.

The net $\mathrm{Na}$ requirements for gain were $7.43 \%$ higher than those recommended by BR-CORTE (2016; Figure 5) considering calves with BW between 40 and $100 \mathrm{~kg}$ and ADG of $1.0 \mathrm{~kg} / \mathrm{d}$. This difference can be attributed mainly to the animal's BW because BR-CORTE (2016) used animals with BW of up to $200 \mathrm{~kg}$ in their estimates. The recommendations of the net $\mathrm{Na}$ requirements for gain of NRC (2001) were higher than those observed in this study. However, this study considered the net $\mathrm{Na}$ requirements for gain as a fixed value of $1.40 \mathrm{~g}$ of Na/ $\mathrm{kg}$ of ADG for animals with BW between 150 and 600 $\mathrm{kg}$ (Guenguen et al., 1989). In addition, for preweaned calves, NRC (2001) suggests $0.40 \%$ of the $\mathrm{Na}$ in milk and $0.15 \%$ of the $\mathrm{Na}$ in the starter feed regardless of intake, BW, breed, and animal performance.

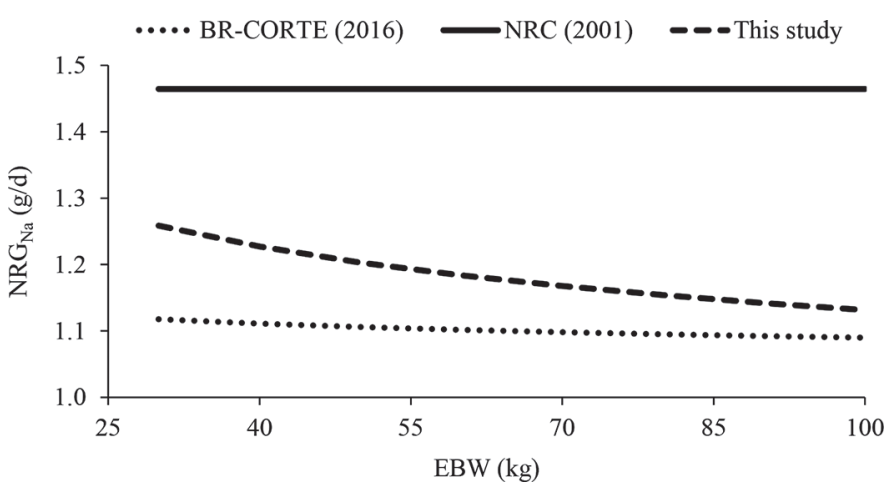

Figure 5. Net Na requirements for growth $\left(\mathrm{NRG}_{\mathrm{Na}} ; \mathrm{g} / \mathrm{d}\right.$; tissue accrual requirement) proposed by the present study, BR-CORTE (2016), and NRC (2001) considering empty BW $(\mathrm{EBW})=1.0 \mathrm{~kg} / \mathrm{d}$. BRCORTE $(2016)$ equation $(\mathrm{g} / \mathrm{d}): \mathrm{NRG}_{\mathrm{Na}}=\mathrm{EBG} \times\left(1.2 \times \mathrm{EBW}^{-0.0209}\right)$; $\mathrm{NRC}(2001)$ equation $(\mathrm{g} / \mathrm{d}): \mathrm{NRG}_{\mathrm{Na}}=1.40 \times \mathrm{ADG}$; this study: $\mathrm{NRG}_{\mathrm{Na}}$ $=1.508 \times \mathrm{EBW}^{-0.045} \times \mathrm{EBG} . \mathrm{EBG}=$ empty body gain $(\mathrm{kg} / \mathrm{d}) . \mathrm{EBW}$ given in $\mathrm{kg}$, $\mathrm{BW}$ given in $\mathrm{kg}$, and $\mathrm{ADG}$ given in $\mathrm{kg} / \mathrm{d}$. 
Dietary Requirements. When calculating dietary requirements of $\mathrm{Na}$ for calves with $\mathrm{BW}$ between 40 and $100 \mathrm{~kg}$ with an ADG of $1.0 \mathrm{~kg} / \mathrm{d}$, the estimates of this study were 1.6 and 2.3 times higher than those reported by NRC (2001) and BR-CORTE (2016), respectively (Table 5). This difference might be attributed to the different methodologies used in this study compared with NRC (2001) and BR-CORTE (2016) to estimate $\mathrm{Na}$ retention or absorption coefficients. Besides the methodology aspect, as apparently those differences are also linked to animals' BW, we suggest using the Na dietary recommendation we observed for preweaned dairy calves.

\section{CONCLUSIONS}

In summary, breed did not affect dietary requirements of microminerals for preweaned dairy calves. The possible existence of a climatic effect on the mineral requirements is evident; however, it is not known what physiological factors are involved in metabolic and requirement changes. Thus, due to the absence of information regarding mineral requirements for preweaned dairy calves, this study is a major advance in this field. However, large differences were observed among the proposed recommendations for preweaned dairy calves compared with those of BR-CORTE (2016) and NRC (2001), suggesting that further studies on mineral requirements for preweaned calves are still necessary to validate the observed estimates and verify long-term effects.

\section{ACKNOWLEDGMENTS}

We are grateful to the following Brazilian foundations for their help with this study: Coordenação de Aperfeiçoamento de Pessoal de Nível Superior (CAPES; Brasilia, DF, Brazil), Conselho Nacional de Desenvolvimento Científico e Tecnológico (CNPq; Brasilia, DF, Brazil), Fundação de Amparo à Pesquisa do Estado de Minas Gerais (FAPEMIG; Belo Horizonte, MG, Brazil), and Instituto de Ciência e Tecnologia de Ciência Animal (INCT-CA; Viçosa, MG, Brazil).

\section{REFERENCES}

AFRC (Agricultural and Food Research Council). 1991. Technical committee on responses to nutrients: Report 6. A reappraisal of the calcium and phosphorus requirements of sheep and cattle. Nutr. Abstr. Rev. 61:576-612.

ARC (Agricultural Research Council). 1980. The Nutrient Requirements of Ruminant Livestock. Gresham Press, London, UK.

Aitken, F. C. 1976. Sodium and Potassium in Nutrition of Mammals. Commonwealth Agricultural Bureaux, Bucksburn, UK.

Allen, L. H. 1982. Calcium bioavailability and absorption: A review. Am. J. Clin. Nutr. 35:783-808.
AOAC International. 2000. Official Methods of Analysis. 17th ed. AOAC International, Washington, DC.

BR-CORTE. 2016. Nutrient Requirements of Zebu and Crossbred Cattle. 2nd ed. Library of Universidade Federal de Viçosa, Viçosa, $\mathrm{MG}$, Brazil

Bronner, F. 1987. Intestinal calcium absorption: Mechanisms and applications. J. Nutr. 117:1347-1352. https://doi.org/10.1093/jn/ 117.8.1347.

Chagas, J. C. C., M. A. Ferreira, A. P. Faciola, F. S. Machado, M. M. Campos, M. R. Entjes, J. L. Donzele, and M. I. Marcondes. 2018. Effects of methionine plus cysteine inclusion on performance and body composition of liquid-fed crossbred calves fed a commercial milk replacer and no starter feed. J. Dairy Sci. 101:6055-6065. https://doi.org/10.3168/jds.2017-13615.

Challa, J., and G. D. Braithwaite. 1989. Phosphorus and calcium metabolism in growing calves with special emphasis on phosphorus homoeostasis. 4. Studies on milk-fed calves given different amounts of dietary phosphorus but a constant intake of calcium. J. Agric. Sci. 113:285-289. https://doi.org/10.1017/S0021859600069951.

Coelho da Silva, J. F. 1995. Requirements for inorganic macroelements for cattle: The ARC/AFRC system and experience in Brazil. Pages 467-504 in Proc. International Symposium on Nutritional Requirements of Ruminants, Viçosa, MG, Brazil.

Costa e Silva, L. F., S. C. Valadares Filho, T. E. Engle, P. P. Rotta, M. I. Marcondes, F. A. S. Silva, E. C. Martins, and A. T. Tokunaga. 2015. Macrominerals and trace element requirements for beef cattle. PLoS One 10:e0144464. https://doi.org/10.1371/journal.pone .0144464 .

CSIRO (Commonwealth Scientific and Industrial Research Organisation). 2007. Nutrient Requirements of Domesticated Ruminants. CSIRO, Collingwood, VIC, Australia.

Detmann, E., M. A. Souza, and S. C. Valadares Filho. 2012. Methods for Feed Analysis. Suprema, Visconde do Rio Branco, Brazil.

Dias, J., M. I. Marcondes, M. F. Noronha, R. T. Resende, F. S. Machado, H. C. Mantovani, and K. A. Dill-Mcfarland. 2017. Effect of pre-weaning diet on the ruminal archaeal, bacterial, and fungal communities of dairy calves. Front. Microbiol. 8:1553. https://doi .org/10.3389/fmicb.2017.01553.

Ellenberger, H. B., J. A. Newlander, and C. H. Jones. 1950. Composition of the bodies of dairy cattle. Bull. 558. Vermont Agric. Exp. Sta., Burlington, VT.

Embrapa. 2009. Racas e tipos de cruzamentos para producao de leite. Circular Tecnica CT 98. Empresa Brasileira de Pesquisa Agropecuaria. Accessed Jan. 10, 2018. http://www.cnpgl.embrapa .br/totem/conteudo/Melhoramento_genetico_e_racas/Circular _Tecnica/CT98_Racas_e_tipos_de_cruzamentos_para_producao _de_leite.pdf.

Fairweather-Tait, S. F., and R. F. Hurrell. 1996. Bioavailability of minerals and trace elements. Members of EC Flair Concerted Action No. 10: Measurement of micronutrient Swiss Federal Institute of Technology Zurich, Laboratory for Human Nutrition. Nutr. Res. Rev. 9:295-324. https://doi.org/10.1079/NRR19960016.

Ferrell, C. L., and T. G. Jenkins. 1998. Body composition and energy utilization by steers of diverse genotypes fed a high-concentrate diet during the finishing period: II. Angus, Boran, Brahman, Hereford, and Tuli sires. J. Anim. Sci. 76:647-657. https://doi.org/10 $.2527 / 1998.762647 \mathrm{x}$.

Fonseca, M. A., S. C. Valadares Filho, L. T. Henriques, P. V. R. Paulino, E. Detmann, E. A. Fonseca, P. D. B. Benedeti, and L. D. Silva. 2012. Nutritional requirements of nursing Nellore calves. Rev. Bras. Zootec. 41:1212-1221. https://doi.org/10.1590/S1516 -35982012000500019 .

Gaucheron, F. 2005. The minerals of milk. Reprod. Nutr. Dev. 45:473483. https://doi.org/10.1051/rnd:2005030.

Goff, J. P. 2017. Mineral nutrition. Pages 667-688 in Large Dairy Herd Management. 3rd ed. D. Beede, ed. American Dairy Science Association, Champaign, IL.

Gueguen, L., M. Lamand, and F. Meschy. 1989. Mineral requirements. Pages 49-56 in Ruminant Nutrition: Recommended Allowances and Feed Tables. R. Jarrige, ed. Institut National de la Recherche Agronomique, London, UK. 
Hansard, S. L., C. L. Comar, and M. P. Plumlee. 1954. The effects of age upon calcium utilization and maintenance requirements in the bovine. J. Anim. Sci. 13:25-26.

Hansard, S. L., H. M. Crowder, and W. A. Lyke. 1957. The biological availability of calcium in feeds for cattle. J. Anim. Sci. 16:437-443.

INRA. 2007. Alimentation Minérale et Vitaminique des Ruminants: Actualisation des Connaissances. 16th ed. INRA, Paris, France.

Jolomba, M. R. 2015. Energy and protein requirements of Holstein-Gir crossbred calves fed with milk added of milk replacer containing increasing levels of dry matter. MS Thesis. Universidade Federal de Viçosa, Viçosa, MG, Brazil.

Khan, M. A., H. J. Lee, W. S. Lee, H. S. Kim, S. B. Kim, K. S. Ki, J. K. Ha, H. G. Lee, and Y. J. Choi. 2007. Pre- and postweaning performance of Holstein female calves fed milk through step-down and conventional methods. J. Dairy Sci. 90:876-885. https://doi .org/10.3168/jds.S0022-0302(07)71571-0.

Kiefer, C., T. M. B. Santos, M. D. S. Moura, C. M. Silva, L. D. S. Lucas, and E. M. Rosa. 2012. Digestibility of diets supplemented with phytase for pigs under different thermal environments. Cienc. Rural 42:1483-1489.

Miranda, E. N., A. C. Queiroz, R. D. P. Lana, R. Mello, A. G. Júnior, F. D. De Resende, and G. F. Alleoni. 2006. Body composition and nutritional requirements of macrominerals of genetically selected Caracu and Nellore and ordinary Nellore young bulls. Rev. Bras. Zootec. 35(Suppl.):1201-1211.

Moulton, C., P. Trowbridge, and L. Haigh. 1922. Studies in animal nutrition II: Changes in proportion of carcass and offal on different planes of nutrition. Accessed Feb. 17, 2018. http://cdm.sos.mo .gov/cdm/ref/collection/agexptstn/id/57212.

NRC. 2001. Nutrients Requirements of Dairy Cattle. 7th rev. ed. National Academy Press, Washington, DC.

Oltenacu, P., and D. Broom. 2010. The impact of genetic selection for increased milk yield on the welfare of dairy cows. Anim. Welf. 19:39-49

Paulino, M. F., C. A. D. A. Fontes, A. M. Jorge, A. C. Queiroz, J. F. C. Silva, and P. G. Júnior. 1999. Body composition and macrominerals (Ca, P, Mg, Na and $\mathrm{K}$ ) requirements of bulls, from four zebu breeds. Rev. Bras. Zootec. 28:634-641. https://doi.org/10.1590/ S1516-35981999000300029

Rodrigues, J. P., J. C. Lima, M. M. Castro, S. C. Filho, M. M. Campos, M. L. Chizzotti, and M. I. Marcondes. 2016. Energy and protein requirements of young Holstein calves in tropical condition.
Trop. Anim. Health Prod. 48:1387-1394. https://doi.org/10.1007/ s11250-016-1102-x.

Schulz, E., H. J. Oslage, and R. Daenicke. 1975. Body composition and deposition of nutrients and energy in growing, fattening bulls. Fortschr. Tierphysiol. Tierernahr. 4:5-70.

Shastak, Y., and M. Rodehutscord. 2015. A review of the role of magnesium in poultry nutrition. World. Poult. Sci. Assoc. 71:125-138. https://doi.org/10.1017/S0043933915000112.

Signoretti, R. D., J. F. C. Silva, S. C. Valadares Filho, J. C. Pereira G. G. L. Araújo, P. R. Cecon, and A. C. Queiroz. 1999. Body composition and net and dietary inorganic macroelements (Ca, P, Mg $\mathrm{K}$ and $\mathrm{Na}$ ) requirements of Holstein calves fed diets with different levels of forage. Rev. Bras. Zootec. 28:205-213. https://doi.org/10 .1590/S1516-35981999000100029.

Silva, A. L., M. I. Marcondes, E. Detmann, F. S. Machado, S. C Valadares Filho, A. S. Trece, and J. Dijkstra. 2015. Effects of raw milk and starter feed on intake and body composition of Holstein $\times$ Gyr male calves up to 64 days of age. J. Dairy Sci. 98:26412649. https://doi.org/10.3168/jds.2014-8833.

St-Pierre, N. R. 2001. Invited review: Integrating quantitative findings from multiple studies using mixed model methodology. J. Dairy Sci. 84:741-755. https://doi.org/10.3168/jds.S0022-0302(01)74530 -4 .

Suttle, N. F. 2010. Mineral Nutrition of Livestock. 4th ed. CAB International, Wallingford, UK.

Underwood, E. J. 1981. The Mineral Nutrition of Livestock. 3rd ed. Academic Press, London, UK.

Underwood, E. J., and N. F. Suttle. 1999. The Mineral Nutrition of Livestock. 3rd ed. CAB International, Wallingford, UK.

Wilson, B. K., M. Vazquez-Anon, D. L. Step, K. D. Moyer, C. L. Haviland, C. L. Maxwell, C. F. O'Neill, C. A. Gifford, C. R. Krehbiel, and C. J. Richards. 2016. Effect of copper, manganese, and zinc supplementation on the performance, clinical signs, and mineral status of calves following exposure to bovine viral diarrhea virus type $1 \mathrm{~b}$ and subsequent Mannheimia haemolytica infection. J. Anim. Sci. 94:1123-1140. https://doi.org/10.2527/jas.2015-9503.

Yuangklang, C., T. Wensing, L. Van den Broek, S. Jittakhot, and A. C. Beynen. 2004. Fat digestion in veal calves fed milk replacers low or high in calcium and containing either casein or soy protein isolate. J. Dairy Sci. 87:1051-1056. https://doi.org/10.3168/jds .S0022-0302(04)73251-8. 